\title{
Appendix Neuroendocrine Tumor Clinical Distant Metastasis TNM Finding v8
}

National Cancer Institute

\section{Source}

National Cancer Institute. Appendix Neuroendocrine Tumor Clinical Distant Metastasis

TNM Finding v8. NCI Thesaurus. Code C135132.

A clinical finding about one or more characteristics of an appendiceal neuroendocrine tumor, following the rules of the TNM AJCC V8 classification system as they pertain to distant metastases. 